\title{
REFERENCES
}

Armitage, E. R., Ashworth, R. de B. \& Ferguson, W. S. (1948). F. Soc. chem. Ind., Lond., 67, 241 . Balch, C. C. (1952). Unpublished.

Balch, C. C. (1957). Brit. F. Nutr. Ir, 213.

Balch, D. A. \& Rowland, S. J. (1957). Brit. F. Nutr. II, 288.

Carrol, E. J. \& Hungate, R. E. (1955). Appl. Microbiol. 2, 205.

Elsden, S. R. (1945). F. exp. Biol. 22, I5I.

Elsden, S. R., Hitchcock, M. W. S., Marshall, R. A. \& Phillipson, A. T. (1946). F. exp. Biol. 22, 191. Gray, F. V., Pilgrim, A. F. \& Weller, R. A. (1951). F. exp. Biol. 28, I 74.

\section{The effect of diurnal variations in composition of the faeces of pigs on the determination of digestibility coefficients by the chromium-oxide method}

\author{
By J. H. MOORE \\ Department of Agricultural Chemistry, University of Reading \\ (Received 25 April 1957)
}

It has frequently been pointed out that the indicator method of determining digestibility coefficients offers no advantage over the direct or conventional method if a composite sample is taken for analysis from the total faecal production during the whole collection period. The indicator method would, however, possess a distinct advantage if quantitative collection of faeces could be dispensed with and digestibility determined accurately from a partial faecal collection. The feasibility of such a simple collection procedure depends largely on variations in composition of faeces excreted at different times of the day. Diurnal variations in the faecal excretion of chromium oxide have been reported by Kane, Jacobson \& Moore (1952), Smith \& Reid (1955), Hardison, Engel, Linkous, Sweeney \& Graf (1956) working with cows, Raymond \& Minson (1955), Pigden \& Brisson (1956) with sheep, Clawson, Reid, Sheffy \& Willman (1955) with pigs and Dansky \& Hill (1952) and Mueller (I956) with poultry. In a number of these papers the influence of variations in the $\mathrm{Cr}_{2} \mathrm{O}_{3}$ content of the excreta on the digestibility of dry matter as determined by the indirect method from faecal samples collected at different times of the day is discussed. Before a simplified $\mathrm{Cr}_{2} \mathrm{O}_{3}$ technique may be applied to determine digestibility coefficients of individual dietary components the nature and extent of the diurnal variations in the faecal excretion of these components must be determined. In experiments with pigs on different feeding treatments Moore (I957) investigated the faecal-excretion patterns of $\mathrm{Cr}_{2} \mathrm{O}_{3}$, crude protein, crude fibre and ash. The form of each excretion curve was found to be related to the feeding system employed, and an explanation based on the relative rates of passage of the different constituents of the diet from the stomach was put forward to account for the observed diurnal variations in faecal composition. In the present 
paper the results of these experiments are considered in terms of the digestibility coefficients of the dietary components as determined by the $\mathrm{Cr}_{2} \mathrm{O}_{3}$ method with a view to evolving a reliable partial faecal sampling technique, i.e. the collection of a relatively small proportion of the daily output of faeces which on analysis would provide an accurate value for the daily digestibility coefficient of any particular nutrient.

\section{EXPERIMENTAL}

Technique and procedure. The results dealt with now are those obtained from Exp. I of a series described in detail by Moore (1957). The experimental diet was given for a preliminary period of ro days to two pigs (nos. 17 and 18 ) housed in metabolism cages. The composition of the basal ration in parts by weight was: ground dredge corn 20 , palm-kernel cake 20 , middlings ${ }_{5}$, bran $\mathrm{I}_{5}$, dried-grass meal 10 , flaked maize 7.5 , maize meal 7.5, dried brewer's yeast 5 . To this basal ration were added $2 \% \mathrm{CaCO}_{3}$, $0.5 \% \mathrm{NaCl}$ and $\mathrm{r} \%$ cod-liver oil. Throughout the experiment, which was divided into three periods, $\mathrm{I} \% \mathrm{Cr}_{2} \mathrm{O}_{3}$ was included in the diet. The basal ration, mineral supplements, cod-liver oil and $\mathrm{Cr}_{2} \mathrm{O}_{3}$ were weighed separately for each meal and mixed thoroughly by hand with sufficient water to produce a feed of such consistency that there was no tendency for the $\mathrm{Cr}_{2} \mathrm{O}_{3}$ to settle out in the feeding trough. The pigs were fed twice daily at $9.30 \mathrm{a} . \mathrm{m}$. and $3.30 \mathrm{p} . \mathrm{m}$. during period A (days I-8), twice

Table 1. Dry matter consumed each day by the experimental pigs ( $g /$ feed)

\begin{tabular}{|c|c|c|}
\hline Experimental conditions & Pig no. 17 & Pig no. 18 \\
\hline \multicolumn{3}{|c|}{ Period A (days $\mathrm{r}-8$ ) } \\
\hline Time of feeding $9.30 \mathrm{a} . \mathrm{m}$. & 360 & $54^{\circ}$ \\
\hline 3.30 p.m. & 360 & $54^{\circ}$ \\
\hline \multicolumn{3}{|c|}{ Period B (days 9-I6) } \\
\hline $\begin{array}{r}\text { Time of feeding } 7.00 \mathrm{a} . \mathrm{m} . \\
7.00 \mathrm{p.m} .\end{array}$ & $\begin{array}{l}630 \\
630\end{array}$ & $\begin{array}{l}630 \\
630\end{array}$ \\
\hline \multicolumn{3}{|c|}{ Period C (days 17-24) } \\
\hline Time of feeding $7.00 \mathrm{a} . \mathrm{m}$. & $54^{\circ}$ & 540 \\
\hline I.00 p.m. & $54^{\circ}$ & 540 \\
\hline 7.00 p.m. & 540 & 540 \\
\hline
\end{tabular}

daily at 7.00 a.m. and 7.00 p.m. during period B (days 9-I6) and three times daily at 7.00 a.m., r.00 p.m. and 7.00 p.m. during period C (days 17-24). Faeces were collected quantitatively during the last 4 days of each period, individual voidings being collected separately immediately after excretion and the time of excretion noted. Some fourteen separate excretions were collected daily from each pig. Food intake was increased at the end of periods A and B. The weights of dry matter consumed by the pigs per day and per feed during the experiment are given in Table $I$.

The faeces were dried at $100-105^{\circ}$, weighed and ground before analysis for $\mathrm{Cr}_{2} \mathrm{O}_{3}$, crude protein and crude fibre.

Methods of analysis. The faeces were analysed for $\mathrm{Cr}_{2} \mathrm{O}_{3}$ by the method of Christian $\&$ Coup (1954-5) and for crude protein and crude fibre by the usual methods (Association of Official Agricultural Chemists, 1950). Since the method of Christian \& Coup $\left(1954^{-5}\right)$ involved a preliminary ashing of the faeces, results were also available for $\mathrm{Cr}_{2} \mathrm{O}_{3}$-free ash. 
Since the collection of faeces during the three periods of the experiment was quantitative, it was possible to calculate the percentage recovery of dietary $\mathrm{Cr}_{2} \mathrm{O}_{3}$ excreted in the faeces. It was found to be consistently low in all periods, and the possible causes of the low recoveries have been discussed previously (Moore, 1957). Therefore, in calculating the digestibility coefficients from the $\mathrm{Cr}_{2} \mathrm{O}_{3}$ values, the corresponding $\mathrm{Cr}_{2} \mathrm{O}_{3}$ faecal recovery factor for each pig in each period (Moore, I957) was inserted into the equation according to the method of Barnicoat (1945-6). Thus, for example, for a $\mathrm{Cr}_{2} \mathrm{O}_{3}$ recovery of $86.3 \%$, the digestibility coefficient $(D)$ is given by the equation

$$
D=100 \frac{X-0.863 Y}{X}
$$

in which $Y$ is the weight ratio of the nutrient to indicator in the faeces and $X$ is the weight ratio of the nutrient to indicator in the food.

\section{Comparison of the conventional and indicator methods of determining digestibility coefficients from total daily collections of faeces}

In view of the fact that food intake and faecal production were measured quantitatively, digestibility coefficients of dry matter, crude protein, crude fibre and $\mathrm{Cr}_{2} \mathrm{O}_{3}$ free ash could be calculated by conventional and indicator methods for each day and each 4 -day period. These values are given in Table 2 and are those which theoretically would have been obtained if the total faecal output per day or per 4 days had been collected, mixed thoroughly and sampled for analysis. With one exception (that of crude fibre for pig no. 17 during period B) the standard deviations of the daily digestibility coefficients from the relative 4 -day coefficient determined by the indicator method were considerably less than the corresponding deviations of the coefficients determined by the conventional method. It may, therefore, be inferred that day-today variations in the composition of the faeces were less important than variations in the amount of faeces excreted daily by the experimental pigs. A similar finding has been reported by Schneider (1955).

\section{Diurnal variations in digestibility coefficients as determined by the indicator method}

If a partial faecal sampling procedure is to be adopted, the extent of diurnal variations in the nutrient digestibility coefficients determined by the $\mathrm{Cr}_{2} \mathrm{O}_{3}$ method on faeces excreted at various times of the day must be considered. From the analytical results it was possible to calculate the standard deviations of the digestibility coefficients of dry matter, crude protein, crude fibre and $\mathrm{Cr}_{2} \mathrm{O}_{3}$-free ash, as determined by the $\mathrm{Cr}_{2} \mathrm{O}_{3}$ method on individual voidings from the corresponding digestibility coefficients that would have been determined by the same method on a composite sample of the total daily collection of faeces. The results are presented in Table 3 , from which it may be observed that diurnal variations in the digestibility coefficients were greatest for crude fibre and smallest for crude protein, which was to be expected in view of the 
Table 2. Digestibility coefficients determined daily for pigs nos. 17 and 18 by the indicator method (I.M.) and by the conventional method (с.м.), together with the standard deviations (s.D.) of these values from the corresponding 4-day coefficients

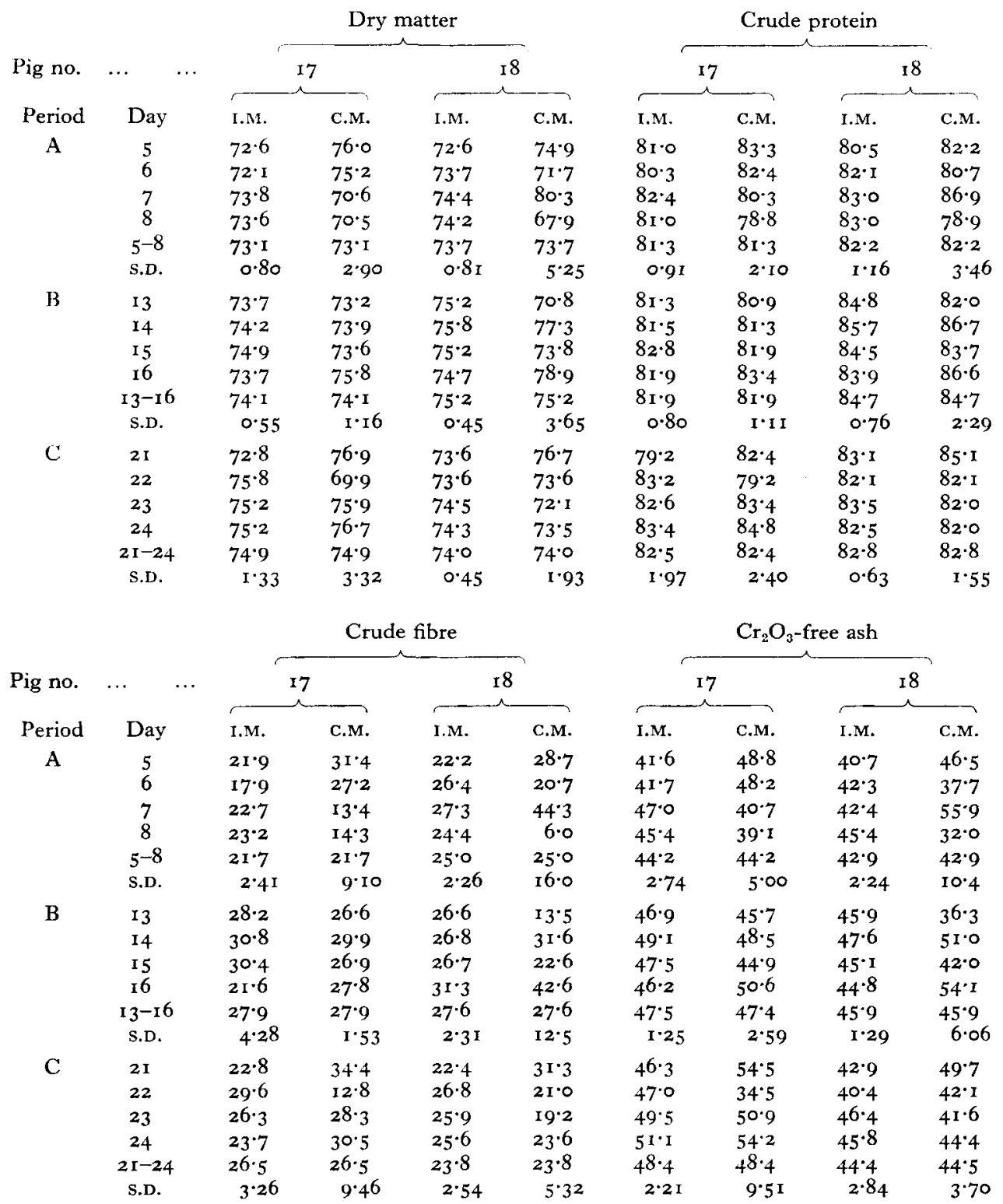

relationships between the faecal-excretion curves of $\mathrm{Cr}_{2} \mathrm{O}_{3}$, crude protein and crude fibre (Moore, 1957). However, it is interesting to note that the diurnal variations in the digestibility coefficients of $\mathrm{Cr}_{2} \mathrm{O}_{3}$-free ash were considerably greater than those for crude protein in spite of the close similarity between the excretion patterns of $\mathrm{Cr}_{2} \mathrm{O}_{3}$, crude protein and $\mathrm{Cr}_{2} \mathrm{O}_{3}$-free ash (Moore, 1957). 
Table 3. Daily and 4-day digestibility coefficients obtained by the indicator method (I.M.) for pigs nos. 17 and 18 and the corresponding standard deviations (S.D.) from these values of digestibility coefficients determined directly on each individual voiding

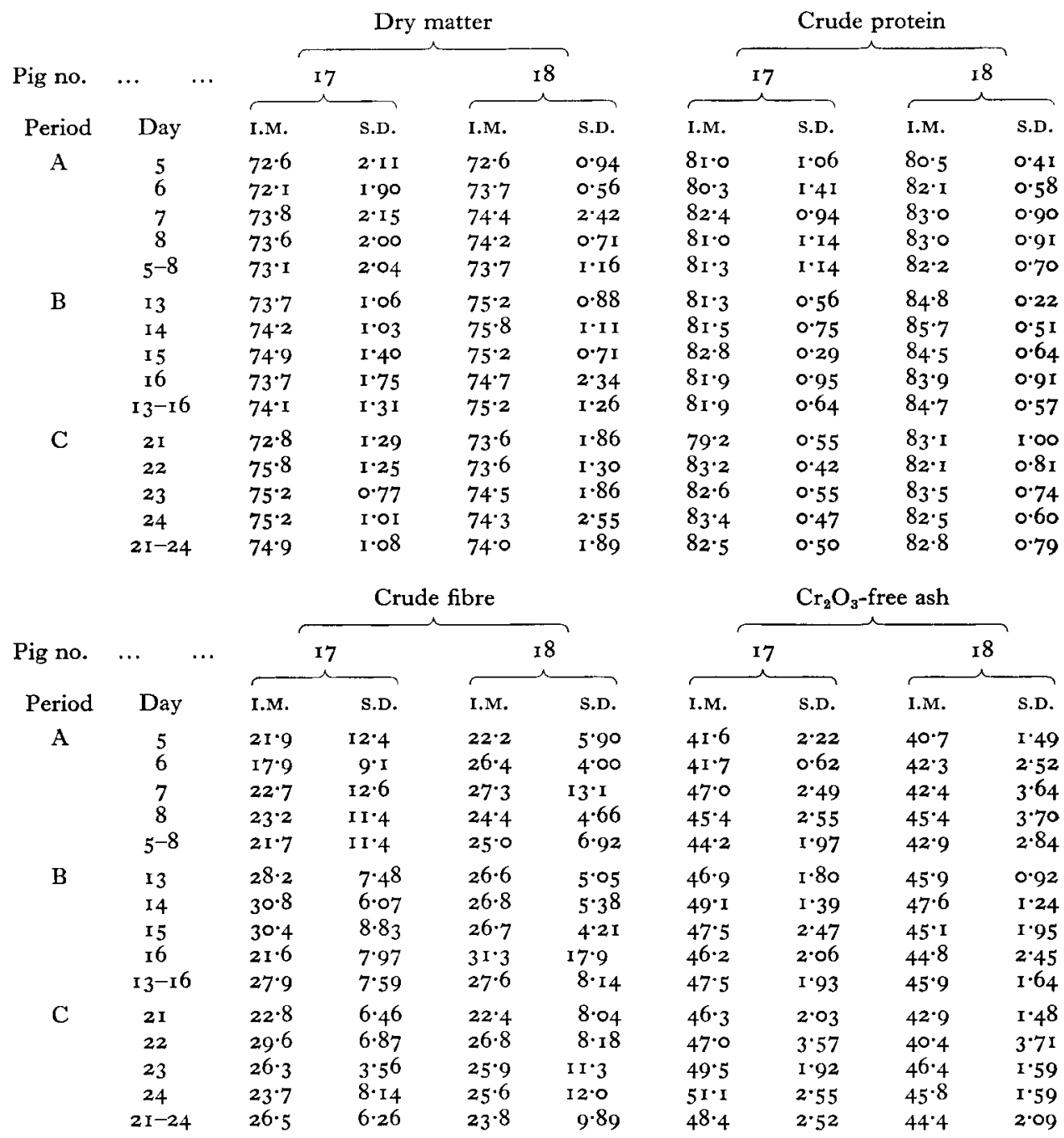

The feasibility of a partial collection procedure

A considerable advance would be made in the experimental technique of digestibility trials if the indicator method could be utilized in conjunction with a random sampling of faeces. The accuracy of such a method would naturally depend on the size and number of samples taken during the day or experimental period, and also, as may be seen from Table 3, on the particular constituent of the diet for which the digestibility was to be determined. Some estimate of the influence of the number of random samples of faeces on the accuracy of the digestibility coefficients determined by analysis of these samples may be gained, for example, from a consideration of the 
results for pig no. 17 on day 13 . The total faecal production for that pig on that day amounted to $33^{8} \mathrm{~g}$ dry matter excreted in the form of fourteen separate voidings of approximately equal weight. Digestibility coefficients of the various dietary constituents determined by the indicator method for the total collection of faeces, and for each of the fourteen samples were thus available. If a random-sampling technique was adopted in which each sample weighed approximately $24 \mathrm{~g}$ dry matter (i.e. the mean weight of dry matter excreted by pigs nos. 17 and 18 in a single voiding), it was

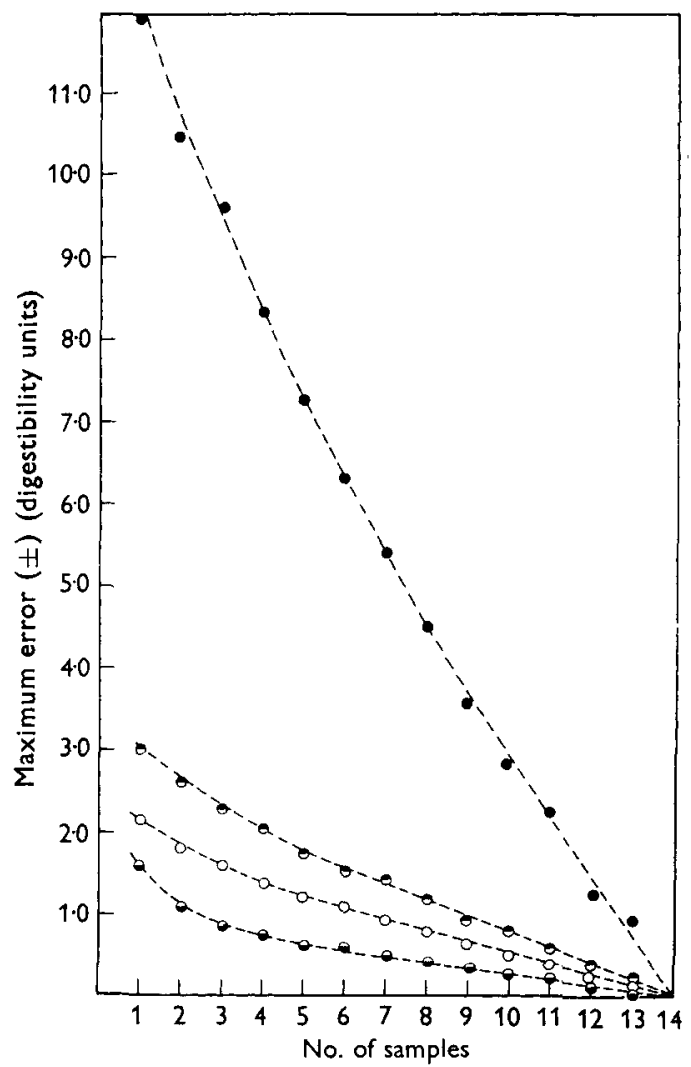

Fig. 1. Effect of the number of random samples of faeces collected on the maximum error involved in the determination of the digestibility coefficients of dry matter, crude protein, crude fibre and $\mathrm{Cr}_{2} \mathrm{O}_{3}$-free ash for pig. no. $\mathrm{I}_{7}$ on day 13. Dry matter, $0-.-0$; crude protein,.---0 ; crude fibre, -.- $\bullet \mathrm{Cr}_{2} \mathrm{O}_{3}$-free ash, $\theta-\ldots$.

possible to calculate the maximum error involved in determining the daily digestibility coefficients by such a technique. These results for pig no. I7 on day $I_{3}$ are presented in Fig. $\mathbf{I}$ in which the maximum error in digestibility units for dry matter, crude protein, crude fibre and $\mathrm{Cr}_{2} \mathrm{O}_{3}$-free ash is plotted against the number of $24 \mathrm{~g}$ samples collected. In this particular instance the maximum error for two random samples each of $24 \mathrm{~g}$ would be the same as that for one random sample of $4^{8} \mathrm{~g}$. Similar results were obtained for each day of the experiment with both pigs. Under the conditions of this experiment it is apparent that a simple random-sampling technique could well be applied to the determination of the digestibility coefficients 
of dry matter, crude protein and $\mathrm{Cr}_{2} \mathrm{O}_{3}$-free ash with a fair degree of accuracy. On the other hand, such a procedure would prove highly unsatisfactory with crude fibre. 'Table 4, for instance, gives the maximum error that would have been involved in the determination of the daily digestibility coefficients of dry matter, crude protein, crude fibre and $\mathrm{Cr}_{2} \mathrm{O}_{3}$-free ash if a random-sampling technique, which consisted of collecting two samples each amounting to approximately 10\% of the total daily faecal production from each pig had been employed in the present experiment.

From Fig. $I$ it is clear that in order to obtain a reliable value for the digestibility coefficient of crude fibre, the number of random samples that must be taken is such as would amount almost to a complete collection of the total daily faecal production. Nevertheless, the indicator method still possesses an advantage over the conventional method of determining the digestibility coefficient of crude fibre, since the quantitative collection of faeces is a problem in many digestibility experiments. If the results obtained for pig no. 17 on day 13 are again considered, it may be calculated that a loss of $10 \%$ of the faeces would introduce a positive error which would result in an increase in the digestibility coefficient of crude fibre from 26.6 to 34.3 (i.e. a maximum error of $+7 \cdot 7$ digestibility units) determined by the conventional method on the assumption that the faeces lost contained the highest percentage of crude fibre in the dry matter. On the other hand, if the $\mathrm{Cr}_{2} \mathrm{O}_{3}$ method had been used to determine the digestibility coefficient of crude fibre it can be calculated that a loss of $10 \%$ of the faeces would result in a maximum error of only $\pm 2 \cdot 3$ digestibility units. The maximum error in digestibility units involved in determining the digestibility of crude fibre by the indicator method if only 80 or $90 \%$ of the faeces had been collected in this experiment is given in Table 5 . The corresponding errors for the digestibility coefficients for dry matter, crude protein and $\mathrm{Cr}_{2} \mathrm{O}_{3}$-free ash are not presented in detail since even with a $20 \%$ loss of faeces the maximum errors for each were considerably less than $\pm \mathbf{I}$ digestibility unit.

\section{DISCUSSION}

Ideally, the indicator method of determining digestibility coefficients should dispense with the quantitative measurement of food intake and faecal production. The digestibility coefficient $(D)$ of a particular nutrient is determined by the indicator method from the equation

$$
D=100-100 \frac{Y}{X}
$$

in which $Y$ is the weight ratio of the nutrient to indicator in the faeces and $X$ is the weight ratio of the nutrient to indicator in the food. Therefore, the reliability of the indicator method depends on the accuracy with which $Y$ and $X$ may be measured. There is a danger that errors in the measurement of $X$ will occur in digestibility experiments when food is rejected. It has been observed that there is a tendency for iron oxide (Heller, Breedlove \& Likely, 1928) and $\mathrm{Cr}_{2} \mathrm{O}_{3}$ (Moore, 1957) mixed intimately with dry food to settle out on mechanical agitation. Should settling out occur in the feed container a considerable error in the digestibility determination will 
Table 4. Maximum error $( \pm)$ in digestibility units involved in determining the digestibility coefficients of dry matter, crude protein, crude fibre and $\mathrm{Cr}_{2} \mathrm{O}_{3}$-free ash in pigs nos. 17 and 18 by a random-sampling technique*

\begin{tabular}{|c|c|c|c|c|c|c|c|c|c|}
\hline \multirow[b]{2}{*}{$\begin{array}{l}\text { Pig no. } \\
\text { Period }\end{array}$} & \multirow[b]{2}{*}{${ }_{\text {Day }} \quad \cdots$} & \multicolumn{2}{|c|}{ Dry matter } & \multicolumn{2}{|c|}{ Crude protein } & \multicolumn{2}{|c|}{ Crude fibre } & \multicolumn{2}{|c|}{$\mathrm{Cr}_{2} \mathrm{O}_{3}$-free ash } \\
\hline & & 17 & I 8 & 17 & I 8 & 17 & 18 & 17 & 18 \\
\hline \multirow[t]{5}{*}{ A } & 5 & $2 \cdot 3$ & 0.6 & $I \cdot \mathbf{I}$ & 0.6 & $12 \cdot 0$ & $5^{\circ}$ & $2 \cdot 9$ & $2 \cdot 1$ \\
\hline & 6 & $I \cdot 4$ & 0.8 & 0.7 & 0.8 & $6 \cdot 7$ & $4 \cdot 5$ & $1 \cdot 0$ & $3 \cdot 3$ \\
\hline & 7 & $2 \cdot 1$ & 0.8 & 0.9 & 0.7 & $1 x \cdot 2$ & 49 & $2 \cdot 9$ & $2 \cdot 8$ \\
\hline & 8 & $2 \cdot 4$ & 0.9 & $I \cdot 4$ & I. & 14.8 & $5 \cdot 5$ & $3 \cdot 5$ & $4 \cdot 5$ \\
\hline & $5^{-8}$ & $2 \cdot 0$ & 0.7 & $\mathbf{I} \cdot \mathbf{I}$ & 0.8 & II $\cdot 0$ & 5.0 & $2 \cdot 6$ & $3 \cdot 2$ \\
\hline \multirow[t]{5}{*}{ B } & I3 & $I \cdot 7$ & $I \cdot 2$ & $I \cdot \mathbf{I}$ & 0.5 & $9 \cdot 9$ & $6 \cdot 7$ & $2 \cdot 7$ & $I \cdot I$ \\
\hline & 14 & $I \cdot 6$ & $I \cdot 2$ & $I \cdot I$ & 0.7 & $8 \cdot 9$ & $6 \cdot 0$ & 2.0 & $1 \cdot 7$ \\
\hline & 15 & $I \cdot 9$ & $\mathrm{r} \cdot \mathrm{O}$ & 0.5 & 0.8 & $8 \cdot 3$ & $6 \cdot 6$ & $3 \cdot 4$ & $2 \cdot 7$ \\
\hline & I6 & $2 \cdot 5$ & $2 \cdot 3$ & $r \cdot 2$ & 0.9 & 10.2 & $25^{\cdot 1}$ & $2 \cdot 9$ & $3 \cdot 1$ \\
\hline & $13-16$ & $\mathrm{I} \cdot 9$ & $I \cdot 4$ & 0.7 & 0.7 & $10 \cdot 6$ & II'I & $2 \cdot 7$ & $2 \cdot I$ \\
\hline \multirow[t]{5}{*}{$\mathrm{C}$} & $2 \mathrm{I}$ & $2 \cdot I$ & $I \cdot 9$ & 0.7 & 0.9 & $9 \cdot 8$ & $8 \cdot 3$ & $2 \cdot 8$ & $2 \cdot 6$ \\
\hline & 22 & $I \cdot 9$ & $2 \cdot 0$ & 0.6 & $I \cdot 6$ & 10.7 & 10.8 & $3 \cdot 7$ & 4.4 \\
\hline & 23 & 0.8 & $I \cdot 4$ & 0.6 & $\mathrm{I} \cdot \mathrm{I}$ & $5 \cdot 0$ & $7 \cdot 9$ & $I \cdot 9$ & $2 \cdot 3$ \\
\hline & 24 & $I \cdot I$ & $2 \cdot 4$ & 0.5 & 0.7 & $8 \cdot 2$ & $12 \cdot 6$ & 3.9 & $2 \cdot 3$ \\
\hline & $21-24$ & $\mathrm{I} \cdot 5$ & I. 9 & 0.6 & $x \cdot I$ & 8.4 & $9^{\circ} 9$ & $3 \cdot I$ & 2.9 \\
\hline
\end{tabular}

* The sampling method consisted of collecting two samples of faeces each day. Each of the two samples amounted to about 10 \% of the total faeces for the day.

Table 5. Maximum error $( \pm)$ in digestibility units involved in determining the digestibility coefficients of crude fibre in pigs nos. 17 and 18 by the indicator method when only 80 or $90 \%$ of the total faeces for the day were collected

\begin{tabular}{|c|c|c|c|c|c|}
\hline \multirow[b]{2}{*}{ Period } & \multirow[b]{2}{*}{ Day } & \multicolumn{2}{|c|}{ Pig no. 17} & \multicolumn{2}{|c|}{ Pig no. 18} \\
\hline & & $\begin{array}{c}80 \% \text { faeces } \\
\text { collected }\end{array}$ & $\begin{array}{l}90 \% \text { faeces } \\
\text { collected }\end{array}$ & $\begin{array}{l}80 \% \text { faeces } \\
\text { collected }\end{array}$ & $\begin{array}{c}90 \% \text { faeces } \\
\text { collected }\end{array}$ \\
\hline \multirow[t]{5}{*}{ A } & 5 & $4 \cdot 2$ & I. 9 & $2 \cdot 2$ & $1 \cdot 0$ \\
\hline & 6 & $3 \cdot 4$ & $I \cdot 5$ & $\mathrm{I} \cdot 7$ & 0.8 \\
\hline & 7 & 3.9 & $I \cdot 7$ & $3 \cdot 3$ & $1 \cdot 4$ \\
\hline & 8 & $4 \cdot 6$ & $2 \cdot I$ & I. 7 & 0.8 \\
\hline & $5^{-8}$ & $4^{\circ} 0$ & $\mathrm{I} \cdot 8$ & $2 \cdot 2$ & $I \cdot O$ \\
\hline \multirow[t]{5}{*}{ B } & 13 & $2 \cdot 3$ & $I \cdot O$ & $\mathrm{I} \cdot 9$ & 0.8 \\
\hline & 14 & $2 \cdot 8$ & $1 \cdot 2$ & $2 \cdot 2$ & $1 \cdot 0$ \\
\hline & I 5 & $4 \cdot I$ & $\mathrm{I} \cdot 8$ & $2 \cdot 0$ & 0.9 \\
\hline & I6 & $3 \cdot 8$ & $\mathrm{I} \cdot 5$ & $5 \cdot 9$ & $2 \cdot 6$ \\
\hline & I $3-16$ & $3 \cdot 3$ & $x \cdot 4$ & $3 \cdot 0$ & $1 \cdot 3$ \\
\hline \multirow[t]{5}{*}{$\mathrm{C}$} & $2 I$ & $2 \cdot 9$ & $I \cdot 3$ & $2 \cdot 8$ & $1 \cdot 8$ \\
\hline & 22 & $3 \cdot 3$ & $I \cdot 4$ & $3 \cdot 1$ & $1 \cdot 4$ \\
\hline & 23 & $I \cdot 3$ & 0.6 & $2 \cdot 6$ & $I \cdot 2$ \\
\hline & 24 & 2.6 & $1 \cdot 2$ & $3 \cdot 8$ & $1 \cdot 7$ \\
\hline & $21-24$ & 2.5 & $I \cdot I$ & $3 \cdot I$ & I. 5 \\
\hline
\end{tabular}

result, unless food refused is collected and analysed for nutrient and indicator. Administration of the indicator in capsules does not eliminate the necessity of measuring food intake.

Errors in the determination of $Y$ arise only when a partial faecal sampling technique is employed. The magnitude of the error will depend primarily on the particular 
nutrient concerned. If the diurnal faecal-excretion patterns of nutrient and indicator are very similar, variations in the value of $Y$ determined in faeces excreted at different times of the day will be relatively small. The similarity between the faecal-excretion curves of crude protein and $\mathrm{Cr}_{2} \mathrm{O}_{3}$ in this experiment with pigs has already been reported (Moore, I957). With pig no. 17 on day 24, for example, a significant direct linear relationship was found between the percentage of crude protein and $\mathrm{Cr}_{2} \mathrm{O}_{3}$ in the dry matter of the faeces, and as a result the value of $Y$ (crude protein) at different times of the day varied only from 4.23 to $4.6 \mathrm{I}$. If a linear relationship of this type existed between the concentration of nutrient and indicator in the faeces and the line passed through the origin, then there would be no diurnal variation in $Y$. It has been shown also that, under the conditions of this experiment, there was an inverse relationship between the percentage of crude fibre and $\mathrm{Cr}_{2} \mathrm{O}_{3}$ in the dry matter of the faeces excreted by the pigs. Variations in $Y$ for crude fibre will, therefore, be comparatively large. With pig no. 17 on day 24 , for instance, $Y$ (crude fibre) varied from $5^{\cdot 12}$ to 6.93. The extent to which diurnal variations in $Y$ influence diurnal variation in the digestibility coefficient $(D)$ of the nutrient depends on the magnitude of $D$. This dependence may be illustrated by reference to the results for crude protein and $\mathrm{Cr}_{2} \mathrm{O}_{3}$-free ash now obtained. Since the faecal-excretion curves for $\mathrm{Cr}_{2} \mathrm{O}_{3}$-free ash were found to be very similar to those for $\mathrm{Cr}_{2} \mathrm{O}_{3}$ and crude protein (Moore, 1957), diurnal variations in $Y$ (crude protein) and $Y\left(\mathrm{Cr}_{2} \mathrm{O}_{3}\right.$-free ash) were of the same order. The values of $X$ for crude protein and $\mathrm{Cr}_{2} \mathrm{O}_{3}$-free ash were $2 \mathrm{I} \cdot \mathrm{O}$ and $6 \cdot \mathrm{I} \mathrm{O}$, respectively. Calculation shows that variations in both $Y$ (crude protein) and $Y\left(\mathrm{Cr}_{2} \mathrm{O}_{3}\right.$-free ash) between 3.66 and 3.46 result in variation of $D$ (crude protein) between 82.6 and 83.5 and $D\left(\mathrm{Cr}_{2} \mathrm{O}_{3}\right.$-free ash) between 40.0 and $43 \cdot 3$, i.e. equal variation in $Y$ results in larger variation in $D$ the lower the value of $D$.

It is thus apparent that a partial faecal sampling procedure in digestibility experiments with $\mathrm{Cr}_{2} \mathrm{O}_{3}$ is particularly suitable when $(a)$ the faecal-excretion curves for the nutrient and $\mathrm{Cr}_{2} \mathrm{O}_{3}$ are 'in phase', i.e. when there is little diurnal variation in $Y$, and (b) the digestibility coefficient of the nutrient is high. The results of this experiment showed that the conditions for $(a)$ and $(b)$ were satisfied by crude protein, those for (a) by $\mathrm{Cr}_{2} \mathrm{O}_{3}$-free ash and those for $(b)$ by dry matter. Neither $(a)$ nor $(b)$ was satisfied by crude fibre. Consequently, reliable values for the digestibility coefficients of crude protein, dry matter and $\mathrm{Cr}_{2} \mathrm{O}_{3}$-free ash could be obtained by the analysis of small samples of faeces (about 10-20\% of the total daily faecal production) collected daily at random from each pig. Reliable values for the digestibility coefficient of crude fibre could be obtained only by an almost complete collection of faeces (about $80-90 \%$ of the total daily faecal production).

Although further work with other animals and diets is necessary, it is possible that the faecal sampling techniques now suggested might be of general application, since there is some evidence that the relationships observed with pigs (Moore, 1957) between the faecal excretion of $\mathrm{Cr}_{2} \mathrm{O}_{3}$, crude protein, $\mathrm{Cr}_{2} \mathrm{O}_{3}$-free ash and crude fibre exist with ruminants. In this respect it is of interest to refer to recent unpublished results of Minson ( 1957 ). Capsules containing $\mathrm{I}^{\circ} \circ \mathrm{g} \mathrm{Cr}_{2} \mathrm{O}_{3}$ were administered twice daily to groups of six sheep on four different grazing treatments. Since the sheep were 
harnessed and fitted with faeces bags, it was possible to collect samples of faeces excreted at different times of the day. Analysis showed that the faecal-excretion curves of $\mathrm{Cr}_{2} \mathrm{O}_{3}$, crude protein and ash were very similar, but opposite to those for 'normal acid' fibre (the fibrous residue left after digesting faeces for I h with $\mathrm{N}-\mathrm{H}_{2} \mathrm{SO}_{4}$ ).

It has been suggested (Kane et al. 1952; Clawson et al. 1955) that in digestibility experiments with $\mathrm{Cr}_{2} \mathrm{O}_{3}$ faeces should be sampled at specific times of the day. Apart from the practical difficulties involved, such a procedure would be valid only if the diurnal variations in the digestibility coefficient of the nutrient followed regular patterns. In this study it was found to be so for dry matter and crude fibre but not for crude protein and $\mathrm{Cr}_{2} \mathrm{O}_{3}$-free ash. The possibility exists, therefore, that the accuracy of a partial faecal sampling technique for the determination of the digestibility of dry matter and crude fibre might be increased if the samples were collected at definite times during the day. However, such a collection technique was found not to be applicable to this experiment for the following reasons. Moore (1957) has shown that the faecal-excretion patterns of $\mathrm{Cr}_{2} \mathrm{O}_{3}$ and crude fibre depend on the method of feeding and also, to a certain extent, on the individuality of each pig. With a particular system of feeding it is possible also that the $\mathrm{Cr}_{2} \mathrm{O}_{3}$ and crude fibre derived from different diets might exhibit different faecal-excretion curves. Unless the patterns of the latter are known for a particular diet, animal and feeding system it would be impossible to predict a suitable time of day at which the faeces should be sampled. Even if the forms of the excretion curves of nutrient and indicator are established, it still remains a problem to decide on a sampling time, for there is considerable day-to-day variation $( \pm 2 \mathrm{~h})$ in the time that faeces of corresponding composition are excreted by a particular pig on a constant feeding treatment (Moore, I957). A further complicating factor is that the digestibility coefficients of crude fibre may show very large variations over very small periods of time. For example, analysis of faeces excreted by pig no. 18 on day I6 at 1.20 p.m., I.30 p.m. and 2.00 p.m. gave digestibility coefficients for crude fibre of $28 \cdot 4,18 \cdot 5$ and $-6 \cdot 95$, respectively, and faeces excreted at $7 \cdot 10$ p.m., 7.20 p.m. and 7.30 p.m. gave coefficients of $59^{\circ} 2,23.4$ and $12 \cdot 2$, respectively.

Whether any advantage is to be gained by using $\mathrm{Cr}_{2} \mathrm{O}_{3}$ in a particular digestibility experiment depends on a number of factors. Quantitative measurement of food intake can be regarded as unnecessary only when it is certain that no stratification of indicator occurs in the feed container. If, for instance, merely the digestibility coefficient of crude protein is required the experiment may be greatly facilitated by the use of $\mathrm{Cr}_{2} \mathrm{O}_{3}$. When the collection of relatively small random samples of faeces is all that is necessary the experimental animals need not be kept in metabolism cages. If the digestibility coefficients to be determined by the $\mathrm{Cr}_{2} \mathrm{O}_{3}$ method include that of crude fibre it would appear that $80-90 \%$ of the faeces must be collected. Nevertheless, the use of $\mathrm{Cr}_{2} \mathrm{O}_{3}$ would still seem to be justified, for even with experiments in metabolism cages where the animals are not fitted with harness and faeces bags it would be possible to reject up to $20 \%$ of the faeces that may be contaminated with urine.

In view of the various reports discussed by Moore (1957) of low recoveries of $\mathrm{Cr}_{2} \mathrm{O}_{3}$ in the faeces, the determination of the recovery of the indicator must be emphasized as a precaution in any digestibility experiment with $\mathrm{Cr}_{2} \mathrm{O}_{3}$. 
SUMMARY

r. The possibility of evolving a simple faecal sampling procedure for determining digestibility coefficients by the indicator method has been investigated in an experiment with pigs given a diet containing $\mathrm{I} \% \mathrm{Cr}_{2} \mathrm{O}_{3}$.

2. In an experiment, the details of which have been given elsewhere (Moore, 1957), two pigs were fed in period $A$ at 9.30 a.m. and 3.30 p.m., in period $B$ at $7.00 \mathrm{a} . \mathrm{m}$. and 7.00 p.m. and in period $\mathrm{C}$ at $7.00 \mathrm{a} . \mathrm{m}$., 1.00 p.m. and $7.00 \mathrm{p} . \mathrm{m}$. After a preliminary period of 4 days on each feeding treatment, voidings were collected separately for 4 consecutive days and analysed for $\mathrm{Cr}_{2} \mathrm{O}_{3}$, crude protein, crude fibre and $\mathrm{Cr}_{2} \mathrm{O}_{3}$-free ash.

3. Comparison of the conventional and indicator methods of determining the daily digestibility coefficients when faeces were collected quantitatively showed that day-today variations in the digestibility coefficients of the various nutrients were less when determined by the $\mathrm{Cr}_{2} \mathrm{O}_{3}$ method.

4. Diurnal variations in the digestibility coefficients as determined by the $\mathrm{Cr}_{2} \mathrm{O}_{3}$ method on samples of faeces excreted at different times of the day were greatest for crude fibre and least for crude protein.

5. Diurnal variations in the digestibility coefficients of crude fibre and dry matter followed regular daily patterns, but those for crude protein and $\mathrm{Cr}_{2} \mathrm{O}_{3}$-free ash did not.

6. The factors on which the accuracy of a partial faecal sampling technique depends are discussed.

7. Under the conditions of the experiment a simple collection procedure, which consisted of taking at random a sample amounting to 10-20\% of the total faecal production, gave reliable results for the digestibility coefficients of crude protein, dry matter and $\mathrm{Cr}_{2} \mathrm{O}_{3}$-free ash.

8. For the determination of the digestibility of crude fibre, the collection of some $80-90 \%$ of the total faeces passed was necessary.

9. Some aspects of the advantages and disadvantages of the indicator method for determining digestibility coefficients are discussed.

\section{REFERENCES}

Association of Official Agricultural Chemists (1950). Official and Tentative Methods of Analysis, 7 th ed. Washington, D.C.: Association of Official Agricultural Chemists.

Barnicoat, C. R. (1945-6). N.Z. F. Sci. Tech. A, 27, 202.

Christian, K. R. \& Coup, M. R. (I954-5). N.Z. F. Sci. Tech. A, 36, 328.

Clawson, A. J., Reid, J. T., Sheffy, B. E. \& Willman, J. P. (r955). F. Anim. Sci. 14, 700.

Dansky, L. M. \& Hill, F. W. (I952). F. Nutr. 47, 449.

Hardison, W. A., Engel, R. W., Linkous, W. N., Sweeney, H. C. \& Graf, G. C. (1956). F. Nutr. 58, 1 I.

Heller, V. G., Breedlove, C. H. \& Likely, W. (x928). F. biol. Chem. 79, 275.

Kane, E. A., Jacobson, W. C. \& Moore, L. A. (1952). F. Nutr. 47, 263.

Minson, D. J. (1957). Private communication.

Moore, J. H. (1957). Brit. F. Nutr. 11, 273.

Mueller, W. J. (1956). F. Nutr. 58, 29.

Pigden, W. J. \& Brisson, G. J. (1956). Canad. F. agric. Sci. 36, 146.

Raymond, W. F. \& Minson, D. J. (1955). F. Brit. Grassl. Soc. 10, 282.

Schneider, W. (1955). Z. Tierernähr. 10, 269.

Smith, A. M. \& Reid, J. T. (1955). F. Dairy Sci. 38, 5 I 5. 